Western University

Scholarship@Western

FIMS Publications

Information \& Media Studies (FIMS) Faculty

2007

\title{
Producing storytime: A collectivist analysis of work in a complex communicative space
}

Pamela J. McKenzie

University of Western Ontario, pmckenzi@uwo.ca

Rosamund Stooke

Follow this and additional works at: https://ir.lib.uwo.ca/fimspub

Part of the Library and Information Science Commons

Citation of this paper:

McKenzie, Pamela J. and Stooke, Rosamund, "Producing storytime: A collectivist analysis of work in a complex communicative space" (2007). FIMS Publications. 46.

https://ir.lib.uwo.ca/fimspub/46 
Producing Storytime: A Collectivist Analysis of Work in a Complex Communicative Space Author(s): Pamela J. McKenzie and Rosamund K. Stooke

Source: The Library Quarterly: Information, Community, Policy, Vol. 77, No. 1 (January 2007), pp. 3-20

Published by: The University of Chicago Press

Stable URL: http://www.jstor.org/stable/10.1086/512953

Accessed: 24-07-2017 21:38 UTC

JSTOR is a not-for-profit service that helps scholars, researchers, and students discover, use, and build upon a wide range of content in a trusted digital archive. We use information technology and tools to increase productivity and facilitate new forms of scholarship. For more information about JSTOR, please contact support@jstor.org.

Your use of the JSTOR archive indicates your acceptance of the Terms \& Conditions of Use, available at http://about.jstor.org/terms

The University of Chicago Press is collaborating with JSTOR to digitize, preserve and extend access to The Library Quarterly: Information, Community, Policy 


\title{
PRODUCING STORYTIME: A COLLECTIVIST ANALYSIS OF WORK IN A COMPLEX COMMUNICATIVE SPACE ${ }^{1}$
}

\author{
Pamela J. McKenzie ${ }^{2}$ and Rosamund K. Stooke ${ }^{3}$
}

Storytime programs for young children are ritual events in the everyday life of the public library. This article analyzes data from two such programs to identify and analyze the work carried out by program leaders, their adult and child participants, and other social actors in other settings (e.g., library CEOs) in order to enable the program to happen. The study builds on research on the public library as a physical space and on the library in the life of the user by describing the often invisible literacy, information, and caring work that goes into accomplishing social settings within the physical space of the library. We contend that the work carried out to produce storytime is both discursively bound and value laden and that storytime participants constitute an emerging discourse community whose work coordinates and is simultaneously coordinated by the ongoing creation and maintenance of its discursive boundaries.

\section{Introduction}

Storytime programs for young children are ritual events in the everyday life of the public library. Although storytimes serve diverse purposes for

1. The authors owe a huge debt of gratitude to the public library users, both children and adults, and the staff and administration for letting us into their spaces and providing ongoing support of our research. We are grateful for the financial support of the American Library Association (Carroll Preston Baber research grant awarded to Lynne McKechnie and Pam McKenzie) and the Social Sciences and Humanities Research Council of Canada (Standard Research Grant awarded to McKechnie, McKenzie, and Stooke). Finally, this work would not have been possible without the intrepid members of the research team who, along with Pam McKenzie, collected data at these two sites: co-investigator Lynne McKechnie and research assistants Brandi Borman, Kirsten Moffatt, and Pam Harris.

2. Associate professor (corresponding author), Faculty of Information and Media Studies, University of Western Ontario, London, Ontario, Canada N6A 5B7; Telephone 1-519-6612111 ext. 88514; Fax 1-519-661-3542; E-mail pmckenzi@uwo.ca.

3. Assistant professor, The University of Western Ontario, John George Althouse Faculty of Education Building, Room 1095, London, Ontario, Canada N6G 1G7; Telephone 1-519661-2111, extension 80454; Fax 1-519-661-3833; E-mail rstooke@uwo.ca.

\author{
[Library Quarterly, vol. 77, no. 1, pp. 3-20] \\ (C) 2007 by The University of Chicago. All rights reserved. \\ 0024-2519/2007/7701-0002\$10.00
}


the library as well as for the families who attend them, professional literature for librarians tends to focus only on the ways that storytime supports early childhood literacy [1] and highlights the work of the program leader [2]. In this article, we take a somewhat different approach, to argue that storytime is not only the product of work carried out by librarians but also of work carried out by adult and child participants and, indeed, by other social actors who may be unknown to members of the local setting, but whose work in other settings affects the education and development of young children and the work of the adults who care for them.

As do researchers working in the ethnomethodological tradition $[3,4]$, we define work broadly to include anything people do that contributes to the accomplishment of the social order of a setting. Wayne Wiegand observed that constrained definitions of "information," "learning," and "education" "have inevitably led the LIS community to think primarily about the user in the life of the library" [5, p. 374]. We likewise argue that constrained definitions of "work" in organizations such as public libraries render important activities invisible and taken for granted, even to those who do the work.

This article draws on data gathered for an ongoing observational study of early learning programs for very young children and their adult caregivers. Our study identifies and analyzes work that enables storytime to take place, including, for example, the social networking of parents and caregivers at storytime. The article builds on studies of the public library as a physical space $[6,7]$ and of the library in the life of the user [5] by describing the often invisible work that goes into accomplishing social settings within the physical space of the library. Moreover, it complements large-scale longitudinal studies that track indicators of children's well-being and evaluative studies that map community assets or assess program effectiveness by illuminating the social processes through which the goals of storytime are realized.

We contend that, at storytime, many kinds of work, including literacy work and information work, are integrally linked and sometimes conjoined with other kinds of work, especially caring work. Several researchers have demonstrated the relationship between information work and caring work, particularly those kinds of caring work more often than not carried out by women in the home. Marjorie DeVault [3, p. 49] found that the work involved in sustaining mealtime conversation "has typically been regarded as trivial, as one of the unremarkable ways that women 'pass time' when they get together." She argued that, "in fact, new ideas are important for each woman's work, and their talk provides one of the ways that they can learn about the essentially private household practices of their peers" [3, p. 49]. Pamela McKenzie [8] found that pregnant women's accounts of seeking information provided important evidence that they were becoming 
appropriately "prepared" for motherhood. Rebecca Tardy [9, p. 436] suggested that the mundane conversations occurring when mothers and children gather together serve "to construct the women's identities, particularly as mothers." She emphasized that the actual talk, independent of any outcomes, was part of the evidence of the caring work of good motherhood. Literacy work too is often carried out in conjunction with caring work. Rosamund Stooke [10] investigated the intersections between literacy work and caring work and reported that children's librarians identified relationship building with families as a necessary component of the work they carry out on behalf of young children's literacy. As one librarian responded to Stooke's question, "What do you do that supports young children's literacy?":

The value of taking five minutes and not even doing the reference work. Just saying to them, "How are you today and are you in school?" Or speaking to the mother. You've made a connection and then there's a bit of trust that seems to develop. I'm just noticing because I've only been at this library for a few months and people are now starting to come up to me and say, "Could you recommend something?" And you had to earn their trust before they were willing to bring big questions. . . . Because, even if you'd had the formal training, the opportunity to make use of it wouldn't have presented itself. . . . You know, it just wouldn't have worked. It took them coming to me. And then I could use that formal knowledge. But I had to build the relationship first. [10, p. 82]

Our analysis is framed by a collectivist perspective, which understands both public library use and information needs, seeking, and use to be "a part of or embedded in a cultural, social, or organisational practice" [11, p. 86; 9]. We work from the premise that storytimes come into being against a backdrop of staffing schedules, room bookings, fire regulations, and the like. The very existence of storytime therefore depends on decisions made earlier and elsewhere. We further propose that as program participants interact socially over a period of several sessions, their interactional work serves to construct each program as a complex communicative space and at the same time to construct its participants as an emerging discourse community. Indeed, we contend that this process has begun before participants arrive at the first program session. Participants may not have met one another prior to attending a program, but their voluntary attendance references specific "ways of coordinating words, thoughts, deeds, values, bodies, objects, tools and technologies, and other people (at appropriate times and places) so as to enact and recognize specific socially situated identities and activities" [12, p. 37] that identify them as members of a discourse community. For example, they may share assumptions about the role storytime plays in the construction of family life [13] or they may 
share the need to be the "right sort" of parent, who gets the child ready for school and all that implies for the child as a future wage earner [4].

Collectivist approaches question the validity of universalistic models and argue against studying "users in general" [11, p. 86] and therefore move away from the perspective of an individual user within a context, "a monologic actor affected by environmental variables" [11, p. 86]. Instead, the focus of analysis in collectivism is the group rather than the individual, and "attention during the research process is focused externally onto the characteristics of the environment" [14, p. 233]. We accordingly attend to the arrangement of the physical space and the form and tempo of the activities carried out in the space before, during, and after the formal programs.

We aim to accomplish two tasks. First, we provide an account of the kinds of work carried out to produce a public library storytime program. Second, we demonstrate ways in which information work and literacy work are conjoined with or embedded in other kinds of work, including seemingly inconsequential activities such as discussions about children's clothing. By so doing, we aim to contribute to critical conversations about everyday life information seeking [15] and to illuminate taken-for-granted aspects of the work of children's librarians [10] and adult and child library users.

\section{Methods}

Our data were collected as part of a naturalistic investigation of early learning programs for very young children and their caregivers. Three members of the research team observed storytime programs targeting young children (birth to thirty-six months) hosted by two neighborhood branches (Mariposa and St. Stephen's Green) of the public library system of a Canadian city of over 100,000 people.

The city where we collected data is typical of central Canadian cities. Its demographics attest to the preponderance of British among its first European settlers and to later emigration from elsewhere in Europe and, more recently, from Asia, Africa, and the Middle East. The library branches were both located in residential neighborhoods and were selected for the different demographic characteristics of those neighborhoods. St. Stephen's Green library is a free-standing building located in an established and affluent neighborhood within walking distance of downtown. The neighborhood's residents are more educated and more likely to speak English as a first language than residents of the city as a whole [7]. Mariposa is a somewhat newer suburban neighborhood where a number of recent immigrants have settled. Its average income, education level, and propor- 
tion of native English speakers are lower than those of St. Stephen's Green, and it has a higher visible minority population. Its library shares a building with a neighborhood community center.

In both locations, between eight and sixteen babies and toddlers attended each of the storytime programs with their caregivers each week. Two caregivers were grandmothers, one a paid babysitter, one a father, and the rest mothers. Older children sometimes accompanied caregivers and young children. Both programs were led by a professional children's librarian.

The research team observed two complete sequences of storytime sessions, one in each branch, for a total of eleven thirty-minute storytimes. The team employed three data collection methods. First, program sessions were observed and audio recorded. During each storytime two or three observers stood or sat in various parts of the room as unobtrusively as possible and made field notes. Second, members of the team observed and talked informally with participants before and after storytime and recorded these data in field notes. Finally, the team conducted semistructured individual and focus group interviews with adult caregivers of children attending storytime. Interviews were semistructured, and questions were developed following the field observation [16]. Interview guides contained questions such as: "Why do you come to this program? What other things do you do with your child(ren)? Is this program different from/ similar to other things you do? How?" All audiotapes were fully transcribed. The study conforms to the ethical guidelines of the Social Sciences and Humanities Research Council of Canada and the Non-Medical Research Ethics Board of the University of Western Ontario, and we have used pseudonyms throughout to protect anonymity.

Consistent with the goals of naturalistic inquiry, we used several strategies to ensure the trustworthiness of the analysis, including prolonged engagement, triangulation of researchers, sites, and methods (observation, interviews), member checking (sharing emerging results with a subset of participants), and peer debriefing (conferring about ongoing analysis with other members of the research team) [17]. We specifically chose a naturalistic research paradigm as it will allow us to explore research questions about which little is now known, enable us to see and understand the programs through the eyes of the participants themselves [18, 19], and provide thick, rich descriptions of the processes involved [20].

\section{Analysis}

The authors have analyzed the data both thematically, in keeping with a grounded theory approach $[17,19]$, and relationally, to identify links be- 
tween work carried out by individuals at storytime and work carried out elsewhere [21]. Our analysis conceptualizes storytime programs not only as settings in which social life is conducted but as ongoing productions in their own right.

We do not wish to convey that the programs we observed are unbounded in time or space. It is clear that the formal component of each session has a ritual opening and closing that separates it from the informal activities that take place before and after. It is also clear that the program is created within limits conferred by the characteristics of the program room and by organizational restraints such as staffing schedules and room availability. As in any stage production, the performance of the actors temporarily transforms the production space. Our analysis therefore first addresses aspects of preproduction work and then identifies some ways that program participants, like actors on a stage, construct and rearrange the space to facilitate certain kinds of activity and constrain other kinds.

Planning a library program for young children embeds administrative work for librarians [10]. Librarians must first schedule the programs and publicize them for potential participants. They must also decide whether or not to limit attendance to registered participants. At Mariposa and St. Stephen's Green libraries, participants are required to register one week prior to the first session. Although attendance is free of charge and nominally open to all, at both locations the high demand for places in a program makes storytime a scarce resource. Unlike programs for families deemed "at risk" where repeat attendance is encouraged, the programs we observed were planned to end after five or six sessions, and in subsequent programs first timers were accommodated before returning families. Some caregivers traveled across the city to circumvent this problem. One caregiver joked that "you can almost do them one right after another if you are willing to drive to other locations." But even first timers sometimes needed to deploy whatever economic, social, and cultural capital [5, 22] they had at their disposal in order to participate. They described registering their friends' children along with their own, and they noted that they relied on one another for information rather than on the library's promotional flyer.

Mother: We also knew that you had to sign up first thing, and [friend] was busy, so I signed up for both the kids. You know, cause I know somebody who phoned up at 10:30 [after the sign-up period began at 9 a.m.] and they couldn't get in. (Focus group transcript, St. Stephen's Green)

Mother: [The brochure] just told me what time to register and when the sessions would be but the mothers are, they give you the true scoop [laughs] of what's good and what's bad, what to avoid, what to seek out more of. It's gotta come from, you gotta get your story from real people. (Follow-up interview transcript, St. Stephen's Green) 
Having surmounted the obstacles presented by the registration process, caregivers routinely sandwich their attendance at library programs into busy schedules that include innumerable other activities: not only adults' paid work but also other educational and recreational activities for the children.

Mother: OK, Monday swimming, Tuesday swimming, Wednesday library, Thursday Kindermusik and sometimes swimming in the afternoon, and Friday I go to a playgroup at [commercial playspace] with other mothers [with similar backgrounds]. Um, and sometimes swimming again in the afternoon. (Follow-up interview transcript, St. Stephen's Green)

[Two mothers are chatting.]

Mother 1: Guess what we saw yesterday in the wagon. We went to [intersection] and saw a whole lot of tractors. They're widening the road and we stayed and watched for half an hour. (Mariposa library, Researcher 1 [R1] field notes/week 5)

Two mothers are chatting: [Baby] may start day care in November one or two days a week, and her mum tells two other mothers how that feels "very sad." She says that she and her husband are going to talk to the daycare people on Tuesday. She then begins to talk to [other] mum about how busy she is these days and says that they just bought an apartment building "so we're doing all that tenant stuff." (St. Stephens Green library, Researcher 4 [R4] field notes/week 4)

Both programs took place in rooms designated by library administrators as multipurpose spaces. These rooms were situated apart from each library's public area. They contained storage cabinets, stacking chairs, and multipurpose foldable tables but were otherwise unfurnished, with walls painted in neutral shades and few additional decorations. A distinguishing characteristic of both rooms was their bareness and the obvious attention paid to child safety features, conditions that afford a librarian an opportunity to create a safe space for very young children and a welcoming one for caregivers.

In library parlance, the work involved in creating a program space within a multipurpose room is known as doing the "set up." The librarian may not do the physical work of setting up the room, but she configures the space in accordance with her vision for the program. Her configuration of the space serves a semiotic function by conveying to participants where to place themselves and their things as well as how to participate. For example, both librarians placed a low stool against one wall to sit on, and stored all the props and books unobtrusively nearby. A large rug or small mats indicated the area where families should sit.

The librarians did a great deal of work to identify and prepare appropriate materials to support their programs. For each storytime session, librarians identified a theme related to the lives of very young children. Their creation, evaluation, and selection of "good" books, rhymes, and other materials therefore allowed them to create a plot for each storytime 
around that theme and based on understandings of child development appropriate to the ages represented in each individual group. A nearby table bore hand-prepared name tags for each participant, pamphlets on library programs, extra copies of the books used in the program, and other books on the same themes. A visit to this table was an almost universal arrival ritual for families:

Child 1 and mum are talking about name tags. Child 1 is wanting Child 2 and his mother [who haven't yet arrived] to have their name tags. Child 2 and his mum walk in.

Child 1: [says names of mother and Child 2].

Child 1 walks over toward the door and gives name tags to Child 2 and mum. Child 2 holds his triumphantly over his head and walks toward his place. (Mariposa, R1 field notes/week 5)

We noted that the children's librarians had also created program spaces such that an outer area of the room functioned as a cloakroom. Strollers and clothes could be stored there, but children were encouraged to remain in the inner circle formed by the adult bodies. Of course, the ongoing space was created and maintained by children as much as by adults, and a safe space from an adult's perspective may be seen by a toddler as an invitation to check out the limits of the space and to challenge them.

Toddler has disappeared [from the coffee room]. Caregiver, urgently: "Careful, don't pinch his fingers!" Sprints through the door between the coffee room and the programme room. . . . I notice that [four-year-old accompanying Toddler and Caregiver] isn't here any more: I'm guessing that she went into her storytime and Toddler headed after her as the door into the storytime room was closing. (Mariposa, R1 field notes/week 3)

Librarians were not the only participants who created spaces within larger spaces. We observed that some families regularly staked out territory while others changed position from week to week. They created family spaces which were hardly noticeable until a four-year-old at Mariposa contested the arrangements by placing herself between two mothers rather than beside her own caregiver. We also observed that caregivers brought with them an array of domestic supplies and equipment that constructed programs as "extensions of domesticity" [23, p. 239].

[Child], who is sitting in front of me, has discovered her mum's purse which was tucked just inside the larger alcove of the wall. She is rooting around in it and pulls out a photo of a group of people. [Child] crumples it a little in her hands, then hands it to her mum. (Green, R4 field notes/week 2)

As storytime began, the circle formed by the adult bodies became less easily permeable by children and adults both: 
The song is interrupted by the arrival of [two babies] and their mums, who cut across the circle and sit down in front of me. . . . The arrivals create sufficient disruption that the song trails off and Librarian, apparently not the least bit thrown off, moves subtly and expertly into the next element of her program to recapture the attention of the mothers and babies. (Green, R4 field notes/week 2)

Far from being controlled entirely by the librarian, the form and tempo of storytime were given an ongoing shape through countless negotiations among participants. Apart from late arrivals, adults breached the circle only when tending to children, either moving about to soothe a fussing infant or, more commonly, moving to retrieve a wayward toddler.

Some elements of storytime are constructed like a performance for which the caregivers and children are the audience. Librarians read books aloud, holding them open toward the children and caregivers. Seemingly inconsequential details such as how an artifact is presented can make important differences in the way storytime unfolds. The Mariposa librarian routinely walked around to show each child a page of a book, a practice that afforded a great deal of both casual conversation and activity but compromised the librarian's ability to control the form and tempo of storytime:

We had a lengthy discussion with Librarian: she talked very reflectively about the balance of facilitating conversation without letting parents' unrelated talk take over. . . . We talked about the logistics of passing out shakers/bells, whether to go around and pass or to pass the container to the caregivers and have them pass it aroundthis is a problem because not all caregivers know what to do and the librarian loses control. We talked about pacing and the fact that you can control the pacing if you stay in charge of the puppets/bells or whatever's being passed. (Green, R1 field notes/week 2)

At other times, all participants are performers. Both librarians used large stuffed animals to be their "baby" and demonstrated the rhymes and bounces on them, either with or without additional verbal instruction, and caregivers responded by repeating the actions with their children.

Librarian: Where's your nose? [All three mothers touch their babies' noses.]

Librarian: Ears? [All three mothers touch their babies' ears.] (Green, R1 field notes/week 1)

Librarians "read" children's bodies and gaze as informative of children's engagement and thereby of the success of their attempts to provide developmentally appropriate programs:

Librarian: This is probably my favourite storytime to do and lots of people say "what do babies do with Books for Babies? Do they pay attention, do they [inaudible] the stories? What do they do?" And I feel like I've got the best place in the room 'cause I'm right up at the front like this and I see, when they sit on 
your lap facing us, I see their expressions and their eyes and it's beautiful. (Green, transcript/week 1)

Caregivers' work during the formal program served primarily to support the librarian's work by ensuring that children could "hear the story." Coordinating children's gaze was an important practice that contributed to this work. By verbally instructing their children and physically moving their bodies, caregivers share powerful consensual understandings about how one ought to behave. At the zoo, such consensus includes the understanding that the animals behind the bars should be the object of focus rather than the bars themselves [13]. At storytime, caregivers' work both explains and constructs appropriate audience and performer behavior:

Librarian: Everybody got their baby on their lap in a place where they can see? [Mother of Toddler 1 groans softly.]

Mother of Toddler 2: No! [laughter and general background noise]

Librarian: That looks great . . . and [inaudible] the circle . . . [general background noise]

Mother of Toddler 1: She's gonna tell us off. No, she specifically said you have to sit down. Look at the book! Look at the book now! Book! (Green, transcript/week 4)

The physical management of artifacts communicated transitions and indicated appropriate activities for various times and places. Toddler 1 had left his spot on the floor beside his mother to stand directly in front of the librarian:

Toddler 1's attention is attracted by the clear, green-lidded plastic container of tickle puppets sitting on top of the storage unit. He points to the box, saying "Doo, doo!"

Mum calls to him: [Name]!

Librarian to Toddler 1: I think your mum's got one.

By this time Toddler 2 has arrived [in front of Librarian] and Librarian has made the decision to stop the rhyme she was getting ready for. She takes down the box, opens it, and gives each of them a tickle puppet, putting the box behind the storage unit. (Green, R1 field notes/week 2)

By removing the puppets to a place inaccessible to the children, the librarian signals that it is time to look at the next book. Caregivers communicated this message to children by physically showing them where they needed to be or moving them there.

Bringing hidden objects into view likewise informed participants of impending transitions. The ending of the formal program was marked by ritual activities involving previously hidden objects and spaces: passing out cookies, opening the door to the room where coffee and cookies would be consumed, putting a basket of board books onto the floor:

Librarian: Okay, I'm going to put down some board books now and I'll come 
around and trade tickle puppets for a cracker if your child can have one. I've also got some booklets over on the side table if anyone is interested. They're called Books for Babies and they talk about the importance of reading to babies; they've got some examples of good books to read. For the very ambitious, it's got patterns for finger puppets in the middle. You can bring those next week if you like [lots of laughter from adults].

Caregiver: I'll get right on that.

Librarian: And a few parenting resources and things like that. So those are there for you to take with you and I'll get some brochures for you next week on some of the rhymes that we do in storytime. (Green, transcript/week 1)

The librarian's narration of these activities embeds several kinds of work in support of storytime. First, the librarian simultaneously acknowledges and challenges the authority of the dominant discourse-that mothers' job is to support literacy by such activities as reading to babies and producing finger puppets. Second, and related, the laughter and ironic response from a mother is indicative of the librarian's success at positioning herself in solidarity with the community of caregivers. Simultaneously, however, her expert knowledge about "the importance of reading to babies" and knowing what are "good books to read" positions her within that discourse as an authoritative information source for caregivers.

Third, the librarian's selection of materials to share both demonstrates her own information work and affords further information work. In describing the crackers, the librarian named a common Canadian brand with the understanding that this would give the caregivers some information about the cookies. "Then I know that she offered the box in case anyone wanted to read the ingredients" (Green, R1 field notes/week 1). This small gesture demonstrates that the librarian shared a community understanding (i.e., that caregivers might be concerned with nutritional information and that reading a cracker box is an appropriate activity) and provided information sources based on that understanding.

Fourth, the librarian chose materials that counted as "good books to read," indicated the library's holdings, reinforced the content of today's storytime, and had been evaluated for their physical condition:

Librarian was setting out the basket of board books, and she and Researcher 2 were talking about how she decides about the board books each week: does she just put out whatever's in the library on the day of storytime? She was telling Researcher 2 that, no, she picks the ones that relate to the theme of today's storytime and those that are in good shape. I asked Librarian about the observation I made last week: when she put the board book basket down and put the books out on the floor, she put one book back onto the table instead of on the floor. She said it was because that particular copy wasn't in very good condition and she likes to put nice-looking ones out. She lamented that it had even been I Went Walking (the 
implication was that this was a good and on-topic book that otherwise would have been an excellent addition). (Green, R1 field notes/week 4)

Finally, it is worth noting that although the librarian's work bears traces of an earlier social organization of children's librarians' work captured in Dee Garrison's phrase "genteel library hostess" [24, p. 126], it in no way references the nineteenth-century children's librarians' proclivity toward moral guardianship.

As the formal activities end, the circle of adult bodies dissolves into looser and more fluid configurations. The librarians leave to prepare for other programs, but most caregivers stay in the room to chat, breast-feed babies, read to toddlers, or watch them play. Babies' and toddlers' need for food and sleep coordinates the adults' activities; some families leave early for nap time:

As I come into the coffee room and set my things on the table beside the door, [infant]'s mum is getting him bundled up to leave. He's wailing. I say "grumpy?" [Infant]'s mum: "He's tired. It's his nap time." [Infant] and mum leave. (Mariposa, R1 field notes/week 3)

while others remain longer in order to breast- or bottle-feed or provide a snack. Both our observations and the tape recorder caught an example:

[Mother 1] and [Mother 2] are talking about bananas-[Mother 1] has just produced one from a bag and is feeding it to [her child]. She says bananas are good because they are sweet and easy to eat. The conversation quickly switches to how long it is taking these days to get their babies dressed, now that the weather is cooler and more layers are required. (Green, R4 field notes/week 4)

Mother 2: Is she eating her banana?

Mother 1: Yeah.

Mother 2: Big old banana.

Mother 1: Yeah. We figure they're [sweet and easy for babies to eat]. (Green, transcript/week 4)

The room has been transformed by the work of all participants from a sitting-and-watching space to a moving-and-touching space:

Librarian: We'll have a little time to just chat amongst ourselves and you can have a look at some books that are good for babies and get to meet each other. You'll notice that the babies' names are on the top of your name tags and underneath that is the name of the person who's brought the baby today, so it makes it easier to talk to them and get to know them a little bit. (Green, transcript/week 1)

The work undertaken by storytime participants does not end with the formal program; it merely changes in form and character, but it remains embedded in both the ongoing social accomplishment and the emergent discourse community. There is no "official" set down, but caregivers and 
some children tidy the toys so that the librarian can return and set up the next program from scratch.

Findings

Our analysis supports the view that the work carried out to produce a library storytime is both discursively bound and value laden. For example, both librarians and caregivers work to assess and maximize children's engagement in the stories and rhymes. Their actions point to a consensual understanding that literacy work is the work here and this takenfor-granted valuing of literacy work establishes a hierarchy of appropriate activities at different times during the program and in different parts of the room. During formal activities initiated by the librarian, children within the inner circle created by the adults and their belongings were encouraged to pay attention to the librarian. Moreover, information sharing among caregivers, which is ostensibly work commensurate with the information mandate of public libraries, was carried out only in the interstices between librarian-initiated activities. It is noteworthy that the librarians did provide parenting and consumer information during formal activities. In both settings, for example, the librarians communicated their sensitivity to caregivers' need to know about the ingredients of the snack crackers they offered to the children. Librarians also alerted caregivers to inexpensive sources of children's books and finger puppets. Paradoxically, they appeared to be using the authority accorded them through program leadership to minimize the asymmetrical relations of power between themselves and the participants. Those actions worked to position them as caregivers "like everyone else."

On completing the formal activities, the librarians relinquished control of activities to the adult caregivers. The librarians in both settings articulated a view that commonalities and connections established among participants through informal talk are valuable outcomes for public library storytime programs. Commonalities and connections are valuable outcomes in their own right, but they are valuable too because they support the library's efforts to provide literacy opportunities for young children. In planning and conducting storytimes, both librarians aimed to create spaces for informal conversation among the adults. They also visited with participants before and after the formal programs and made sure that the storytime spaces remained available to participants-despite the many competing demands for their time and the competing demands for the use of the physical space. As noted earlier, the St. Stephen's Green librarian remarked that storytime aims to provide both access to literacy for children and access to parenting networks and information for adults. 
The work of establishing commonalities was distributed among the librarians, the caregivers, and the children, whose appearances and actions provided the impetus for and the topics of much of the conversation among caregivers. For example, after one session at St. Stephen's Green, several mothers were engaged in the exchange of birth stories, but they adapted their conversation to include another mother's adoption story when it became evident that she did not have a birth story to share. The baby, whose skin was a different color from her mother's, had been adopted from another country. A discussion of the baby's shoes started a conversation that included the mother's story of how the baby had come to live with her family. It is worth noting that the conversation provided an opportunity for mothers to discuss the baby's origins without drawing attention to race while simultaneously establishing a very new mother's credentials as "one of us."

Mother 1: I love those shoes.

Mother 2: We got them in [other country], actually.

Mother 1: Really?

Mother 2: Oh my god, there were so many pairs of shoes 'cause they were allthese were all leather shoes and they cost $\$ 2.00$.

Mother 1: Oh my gosh!

Mother 2: They're so expensive here, so I got some for when she's grown too.

Mother 1: [Inaudible] She's doing okay though?

Mother 2: Yeah, she's doing really well. We've been together since [two months ago], so, uh, she seems to be attaching to me [inaudible]. [Baby cries.]

Mother 1: How old was she?

Mother 2: She was 10 months.

Mother 1: Right. So did it take some time to adjust?

Mother 2: It was very hard. [Inaudible]

Mother 1: She looks very happy.

Mother 2: Yeah, she's got a great personality. (Green, transcript/week 1)

It is also worth noting that in addition to establishing commonalities among participants, the mothers' conversation worked to construct a shared understanding of "normal" child development and to validate this mother's work $[4,18]$. The purchase of distinctive shoes for such a good price presented the mother as a savvy shopper capable of broadening the options ordinarily available to her at home. However, the cost of travel and any costs of the adoption were not factored into the bargain price of the shoes. The caregivers' talk interpreted and defined the child's clothing for one another, enabling a child unable to talk on her own to inform through her appearance.

As in other settings in which caregivers and young children gather together [9], participants developed and maintained boundaries that defined the range of topics open and not open for casual conversation. Whereas 
literacy work was privileged during the formal part of the program, the informal conversation among participants largely covered topics related directly to domestic life and child care (e.g., consumerism, homemaking and household hints, caring and family life, and health). It is instructive to consider what was not talked about. Although mothers shared birth stories, we did not hear discussions of postpartum physical and psychological changes. Although there was much talk about children's clothing and footwear, we did not hear much talk about adults' clothing or about the material resources required in order to acquire clothing. Indeed, the tone of the conversation was generally light, with few references to the kinds of topics addressed in parenting programs:

Mother 1: And the other [programs] are a resource for the parents as far as any discipline problems you are having, they have resources, like people who know about taking care of children, you can ask them about stuff, where as this is more like learning from the experiences of other mums.

Mother 2: They're ECE workers [with special credentials in early childhood education] that run them.

R1: So people who are trained.

Mother 2: Yeah. They're ECE workers that run them and they have other people come in, like special needs resourcing and things like that, or they have hearing clinics and do the testing for three-year-olds and all that stuff.

Mother 1: Yeah, and like [inaudible] baby, they have postnatal depression classes and you know, things like that. (Green, focus group transcript)

As did the librarians, we contend that the literacy work carried out during the storytime program is often conjoined with information work and/or caring work and that these are mutually constitutive. While Harris cautions librarians against confusing activity with purpose [25, p. 3], we argue that literacy activities afford opportunities for the acquisition of social capital through informal information seeking, giving, and use [5]. Conversely, information and caring work carried out by all the adults creates a fertile ground in which caregivers and children can cultivate family literacy practices conducive to children's future success in school. The diverse activities that constitute storytime therefore contribute in many ways to the purposes of the public library and also to family life.

\section{Conclusion}

We have characterized the public library storytime as a complex communicative space. In addition to introducing caregivers to library resources and providing very young children with a print-filled environment, a public library storytime affords and embeds many kinds of social 
activity. At first glance much of the work of storytime, which is accomplished through the use of talk, bodies, and artifacts, is not visible. However, a collectivist perspective and a generous definition of "work" allow us to adjust the scope of our lens in ways that bring previously hidden work into view.

Additionally, a collectivist perspective allows us to begin to identify ways in which actions carried out by individuals at a storytime are linked to actions carried out by social actors in other settings. The work of CEOs and library planners is linked through the creation and use of organizational texts such as building blueprints, staffing schedules, and strategic plans to the work of frontline professionals and library users. Moreover, the work of administrators and planners is linked through the creation and use of government documents, advertising, and other media texts to work carried out in government offices and corporations.

There is evidence too that activities at storytime are organized through the ongoing creation and maintenance of its discursive boundaries. It is not as easy to recognize this work or to apprehend its extralocal organization. As Foucault has argued, discourses are "practices that systematically form the objects of which they speak" [26, p. 49]. They lack the concreteness of texts, even digital ones, and they eschew critique. Indeed, discourses are powerful for precisely that reason. Nevertheless, we identified events in which discourses that are active in diverse sites appear to be organizing the activities of individuals at a storytime. A caregiver's efforts to orient a baby's gaze toward the librarian, for example, can be linked to an unstated but widely held expectation that children should arrive at school with the ability to attend to instructions and to listen well. Nothing may be further from the caregiver's mind, of course, but the action references ideas about early child development and care work that permeate parent advice literature and policy texts such as the Organization for Economic Cooperation and Development's Starting Strong [27].

Finally, a collectivist perspective and a generous definition of "work" allow us to catch a glimpse of the complex and sometimes contradictory roles that public libraries play in the lives of users. While it is fair to acknowledge the role that storytime plays in preparing children for future success at school, it is also worth noting that storytime survives as a ritual event in the life of the public library because it provides a space for spontaneity and joy. The St. Stephen's Green librarian's "off the cuff” remark about finger puppets serves to remind us first, that storytime affords opportunities for participants to contest "taken-for-granted" ideas and turn them on their heads and second, that no definition of "work" should underestimate the value and importance of play. 


\section{REFERENCES}

1. Gillen, Julia, and Hall, Nigel. "The Emergence of Early Childhood Literacy." In Handbook of Early Childhood Literacy, edited by Nigel Hall, Joanne Larson, and Jackie Marsh, pp. 3-12. London: Sage, 2003.

2. Stooke, Roz. “'Many Hands Make Light Work' but 'Too Many Cooks Spoil the Broth': Representing Literacy Teaching as a 'Job for Experts' Undermines Efforts to Involve Parents." Journal of Curriculum Studies 37 (February 2005): 3-10.

3. DeVault, Marjorie. Feeding the Family: The Social Organization of Caring as Gendered Work. Chicago: University of Chicago Press, 1991.

4. Griffith, Alison I., and Smith, Dorothy E. Mothering for Schooling. London: Routledge, 2005.

5. Wiegand, Wayne. "To Reposition a Research Agenda: What American Studies Can Teach the LIS Community about the Library in the Life of the User." Library Quarterly 73 (October 2003): 369-82.

6. Leckie, Gloria J., and Hopkins, Jeffrey. "The Public Place of Central Libraries: Findings from Toronto and Vancouver." Library Quarterly 72 (July 2002): 326-72.

7. McKenzie, Pamela J.; Prigoda, Elena M.; Moffatt, Kirsten; and McKechnie, Lynne (E. F.). "Behind the Program-Room Door: The Creation of Parochial and Private Women's Realms in a Canadian Public Library." In The Library as Place, edited by Gloria J. Leckie and John Buschman, pp. 117-34. Westport, CT: Greenwood, forthcoming.

8. McKenzie, Pamela J. "Justifying Cognitive Authority Decisions: Discursive Strategies of Information Seekers.” Library Quarterly 73 (July 2003): 261-88.

9. Tardy, Rebecca W. "'But I am a good mom': The Social Construction of Motherhood through Health-Care Conversations." Journal of Contemporary Ethnography 29 (August 2000): 433-73.

10. Stooke, Rosamund K. "Healthy, Wealthy and Ready for School: Supporting Young Children's Education and Development in the Era of the National Children's Agenda." PhD diss., University of Western Ontario, 2004.

11. Talja, Sanna; Tuominen, Kimmo; and Savolainen, Reijo. "'Isms' in Information Science: Constructivism, Collectivism, and Constructionism." Journal of Documentation 61 (January 2005): 79-101.

12. Gee, James Paul. "A Sociocultural Perspective on Early Literacy Development." In Handbook of Early Literacy Research, edited by Susan B. Neuman and David K. Dickinson, pp. 30-42. New York: Guilford, 2001.

13. DeVault, Marjorie. "Producing Family Time: Practices of Leisure Activity beyond the Home.” Qualitative Sociology 23 (Winter 2000): 485-503.

14. Hartel, Jenna. "The Serious Leisure Frontier in Library and Information Science: Hobby Domains." Knowledge Organization 30, no. 3-4 (2003): 228-38.

15. Savolainen, Reijo. "Everyday Life Information Seeking: Approaching Information Seeking in the Context of 'Way of Life'." Library and Information Science Research 17 (Summer 1995): 259-94.

16. Warren, Carol A. B. "Qualitative Interviewing." In Handbook of Interview Research, edited by Jaber F. Gubrium and James A. Holstein, 83-101. Thousand Oaks: Sage, 2002.

17. Lincoln, Yvonna S., and Guba, Egon G. Naturalistic Inquiry. Newbury Park, CA: Sage, 1985.

18. Strauss, Anselm, and Corbin, Juliet. Basics of Qualitative Research: Techniques and Procedures for Developing Grounded Theory. 2nd ed. Thousand Oaks, CA: Sage, 1998.

19. Mellon, Constance A. Naturalistic Inquiry for Library Science: Methods and Applications for Research, Evaluation, and Teaching. New York: Greenwood, 1990.

20. Singleton, Royce; Straits, Bruce C.; Straits, Margaret Miller; and McAllister, R. J. Approaches to Social Research. New York: Oxford University Press, 1988. 
21. Campbell, Marie, and Frances Gregor. Mapping Social Relations: A Primer in Doing Institutional Ethnography. Aurora, ON: Garamond, 2002.

22. Bourdieu, Pierre. "The Forms of Capital." In Handbook of Theory and Research for the Sociology of Education, edited by John G. Richardson, pp. 241-58. Westport, CT: Greenwood, 1986.

23. Blackford, Holly. "Playground Panopticism: Ring-around-the-Children, a Pocketful of Women." Childhood 11 (May 2004): 227-49.

24. Garrison, Dee. Apostles of Culture: The Public Librarian and American Society, 1876-1920. New York: Free Press, 1979.

25. Harris, Michael. "The Role of the Public Library in American Life: A Speculative Essay." University of Illinois Graduate School of Library and Information Science Occasional Paper 117, 1975.

26. Foucault, Michel. The Archeology of Knowledge and the Discourse on Language. New York: Pantheon, 1972.

27. Organization for Economic Cooperation and Development. Starting Strong: Early Childhood Education and Care. Paris: Organization for Economic Cooperation and Development, 2001. 